\title{
Trend analysis of the utilization of antiepileptic drugs in pregnant women with epilepsy in Moravian-Silesian region of the Czech Republic
}

\author{
Ivana Kacířová', ${ }^{2}$, Milan Grundmann' \\ 'Department of Clinical Pharmacology, Faculty of Medicine, University of Ostrava \\ ${ }^{2}$ Department of Clinical Pharmacology, Department of Laboratory Diagnostics, University Hospital Ostrava
}

\begin{abstract}
Aim: Little is known about the consumption of antiepileptic drugs in pregnancy in the Czech Republic, particularly for newer agents. In our previous paper, we discussed long-term trends in the utilization of antiepileptic drugs during pregnancy in a group of 235 women between 1991-2006. Currently, we continue to investigate the long-term trends in antiepileptic drug use in pregnant women.
\end{abstract}

Method: A retrospective study analysed data from 208 pregnant women receiving antiepileptic drugs between January 2007 and May 2016. The request forms for routine therapeutic drug monitoring were used as the data source. Mono- versus polytherapy, the utilization of individual antiepileptic drugs, and the utilization of combinations were analyzed during two periods (2007-2011, 2012-2016) and the data were compared with our previous study.

Results: Monotherapy was used during the first period (2007-2011) in 83\% of women and during the second period (2012-2016) in $68 \%$ of women, which was significantly lower. The most frequently prescribed antiepileptic drugs were lamotrigine, valproic acid, and carbamazepine during 2007-2011, and lamotrigine, levetiracetam, and carbamazepine during 2012-2016. Carbamazepine + valproic acid was found as the most widely administered combination during 2007-2011 and lamotrigine + levetiracetam during 2012-2016.

Conclusions: Our study demonstrates the long-term trends in the utilization of antiepileptic drugs in pregnant women with epilepsy. A significant shift from phenytoin, carbamazepine, and primidone to carbamazepine, lamotrigine, and valproic acid was found between 1991-2006, and from lamotrigine, valproic acid, and carbamazepine to lamotrigine, levetiracetam, and carbamazepine between 2007-2016. Prescription of valproic acid has declined during 2007-2016 with an increase in the use of newer antiepileptic drugs, which is concordant with the current recommendations.

Key words: antiepileptic drugs, pregnancy, monotherapy, polytherapy.

Analýza vývoje používání antiepileptik u těhotných žen s epilepsií v Moravskoslezském kraji

Cíl: Informace o používání antiepileptik během těhotenství v České republice jsou omezené, a to zejména v případě tzv. „nových” antiepileptik. V naší předchozí práci jsme prezentovali dlouhodobé trendy při užívání antiepileptik během těhotenství v souboru 235 žen v rozmezí let 1991-2006. Nyní představujeme další rozbor vývoje podávání antiepileptik u těhotných žen.

Metoda: V této retrospektivní studii jsou analyzovány údaje 208 těhotných žen užívajících antiepileptika od ledna roku 2007 do května roku 2016 získané ze žádanek pro rutinní terapeutické monitorování. Ve dvou obdobích (2007-2011, 2012-2016) je sledován výskyt mono- versus polyterapie, používání jednotlivých antiepileptik a jejich kombinace. Získaná data jsou porována s výsledky našeho předchozího výzkumu.

Výsledky: Monoterapie byla použita během prvního období (2007-2011) u 83 \% žen a během druhého období (2012-2016) u 68\% žen, kdy došlo k signifikantímu poklesu. Nejčastěji užívanými antiepileptiky byly lamotrigin, kyselina valproová a karbamazepin v letech 2007-2011, a lamotrigin, levetiracetam a karbamazepin v období 2012-2016. Karbamazepin+kyselina valproová byla nejčastěji předepisovaná kombinace během 2007-2011 a lamotrigin+levetiracetam během 2012-2016. 


\section{| hLAVNÍ TÉMA}

TREND ANALYSIS OF THE UTILIZATION OF ANTIEPILEPTIC DRUgS IN PREGNANT WOMEN WITH EPILEPSY IN MORAVIAN-SILESIAN REGION OF THE CZECH REPUBLIC

Závěry: Tato studie demonstruje dlouhodobé trendy v užíání antiepileptik u těhotných epileptiček. V letech 1991-2006 došlo k významnému posunu od fenytoinu, karbamazepinu a primidonu ke karbamazepinu, lamotriginu a kyselině valproové a mezi roky 2007-2016 od lamotriginu, kyseliny valproové a karbamazepinu k lamotriginu, levetiracetamu a karbamazepinu. Předpis kyseliny valproové byl v období 2007-2016 snížen se současným nárůstem používání "nových" antiepileptik, což je ve shodě se současnými doporučeními.

Klíčová slova: antiepileptika, těhotenství, monoterapie, polyterapie.

\section{Introduction}

Women with epilepsy are advised to continue antiepileptic drugs (AEDs) during pregnancy to reduce maternal and fetal trauma associated with seizures. On the other hand, the goal of treatment with AEDs during pregnancy is optimal seizure control with minimal in utero fetal exposure to AEDs in an effort to reduce the risk of structural and neurodevelopmental teratogenic effects (1). Data from pregnancy registries have consistently shown, that valproic acid (VPA) is associated with a greater risk of fetal major congenital malformations (MCM) than other AEDs in monotherapy as well as in polytherapy. The risk of teratogenic effects of AEDs appears to be dose dependent, which has been most clearly demonstrated also for VPA (2). On the other hand, in our previous study we found a significant inverse correlation between birth length and weight and maternal and umbilical cord VPA concentrations, but not dose (3). The knowledge of the teratogenic potential of newer generation AEDs other than lamotrigine (LTG) is limited. Data on levetiracetam (LEV) are accumulating, and so far suggest MCM rates similar to those seen with LTG or carbamazepine (CBZ), whereas signals indicate higher rates with topiramate (TMP) (2). Management of epilepsy during pregnancy continues to be challenging, although recent studies provide high quality information to guide clinical decision making. Conclusions from these studies reinforce the following. First, VPA use should be avoided in women of childbearing age whenever possible. If a woman's seizures can only be controlled by VPA after all reasonable AED alternatives have failed, then VPA shouId be used at the lowest dosage possible to obtain reasonable seizure control. Attempts should be made to maintain VPA daily dosage $<700 \mathrm{mg}$ per day. Second, the number and dose of AEDs during the first trimester should be minimized to reduce the risk of MCM for the developing fetus, while maintaining seizure control based on the individual's epilepsy characteristics and target concentration. Third, LTG and LEV, in monotherapy and polytherapy use, are comparatively less teratogenic and are therefore considered favorable drugs for the management of epilepsy during pregnancy. Lastly, therapeutic drug monitoring in some patients may help prevent seizure deterioration during pregnancy (1). Little is known about the consumption of AEDs in pregnancy in the Czech Republic, particularly for "newer" AEDs. In our previous paper we discussed long-term trends in the utilization of AEDs during pregnancy in a group of 235 women within three 5 -year periods between 1991-2006. Monotherapy was used in $61 \%$ in 1991-1995, in 68\% in 1996-2000, and in $76 \%$ in 2001-2006. During the $1^{\text {st }}$ period, the most frequently prescribed AEDs were phenytoin (PHT), carbamazepine and primidone (PRM), during the $2^{\text {nd }}$ period, carbamazepine, phenytoin, and valproic acid, and during the $3^{\text {rd }}$ period, carbamazepine, lamotrigine, and valproic acid. The data demonstrated a significant shift from poly- to monotherapy and from the first- and second-generation to the second- and third-generation of AEDs in pregnant women suffering from epilepsy (4). Currently, we continue in investigation of long-term trends in AEDs use in women with epilepsy during pregnancy between January 2007 and May 2016.

\section{Method}

The retrospective study analysed data from 208 pregnant women with epilepsy receiving AEDs at the time of delivery between January 2007 and May 2016. The request forms for routine therapeutic drug monitoring (TDM) in University Hospital Ostrava (Czech Republic) were used as the data source. AEDs mono-versus poly-therapy, the utilization of individual AEDs and the utilization of combinations of AEDs were analyzed during two study periods (2007-2011, 2012-2016) and data were compared with our previous study (4). Statistical analysis was performed using GraphPad Prism version 5.00 for Windows, GraphPad Software (San Diego, CA, USA www.graphpad.com). The D'Agostino and Pearson omnibus normality test was applied for test if the values come from a Gaussian distribution. Thereafter, we used the unpaired t-test (when the values follow the Gaussian distribution) or the nonparametric MannWhitney test for the comparison of the distributions of two unmatched groups, and also Fisher's exact test. A value of $p<0.05$ was considered statistically significant. Maternal age and weight are presented in Table 1. For the treatment characteristics, see Tables 2 and 3 (total daily dose and daily dose related to the body weight).

Tab. 1. Characteristics of cohort: maternal age (years) and weight ( $\mathrm{kg}$ ), comparison with our previous study (4); weight has not been recorded in all cases

\begin{tabular}{|l|c|c|c|c|c|c|c|c|}
\hline & $\mathbf{N}$ & $\begin{array}{c}\mathbf{2 0 0 7 - 2 0 1 1} \\
\text { mean } \pm \text { SD (median; range) }\end{array}$ & $\mathbf{N}$ & $\begin{array}{c}\mathbf{2 0 1 2 - 2 0 1 6} \text { mean } \pm \text { SD } \\
\text { (median; range) }\end{array}$ & $\mathbf{N}$ & $\begin{array}{c}\mathbf{2 0 0 7 - 2 0 1 6} \\
\text { mean } \pm \text { SD (median; range) }\end{array}$ & $\begin{array}{c}\mathbf{N} \\
\mathbf{1 9 9 1 - 2 0 0 6}(\mathbf{4}) \mathbf{m e a n} \pm \text { SD } \\
(\mathbf{m e d i a n} ; \text { range) }\end{array}$ \\
\hline age (years) & 117 & $\begin{array}{c}29 \pm 5 \\
(29 ; 18-42)\end{array}$ & 91 & $\begin{array}{c}28 \pm 5 \\
(28 ; 18-41)\end{array}$ & 208 & $\begin{array}{c}28 \pm 5 \\
(28 ; 18-42)\end{array}$ & $\begin{array}{c}235 \pm 5 \\
(26 ; 16-41)^{*}\end{array}$ \\
\hline weight (kg) & 113 & $\begin{array}{c}75 \pm 12 \\
(74 ; 48-115)\end{array}$ & 85 & $\begin{array}{c}80 \pm 13 \\
(78 ; 56-125)^{* *}\end{array}$ & 198 & $\begin{array}{c}77 \pm 13 \\
(76 ; 48-125)\end{array}$ & $\begin{array}{c}76 \pm 13 \\
(75 ; 43-124)\end{array}$ \\
\hline
\end{tabular}

${ }^{*} p<0.0001: 2007-2016$ versus 1991-2006

** $p<0.03: 2007-2011$ versus 2012-2016 
HLAVNÍ TÉMA 【

TREND ANALYSIS OF THE UTILIZATION OF ANTIEPILEPTIC DRUGS In PREGNANT WOMEN WITH EPILEPSY IN MORAVIAN-SILESIAN REGION OF THE CZECH REPUBLIC

Tab. 2. Total daily dose ( $\mathrm{mg}$ ) of antiepileptic drugs and comparison with our previous study (4); values has not been recorded in all cases

\begin{tabular}{|c|c|c|c|c|c|c|c|c|}
\hline AED & $\mathrm{N}$ & $\begin{array}{c}\text { 2007-2011 } \\
\text { mean } \pm \text { SD (range) }\end{array}$ & $\mathrm{N}$ & $\begin{array}{c}\text { 2012-2016 } \\
\text { mean } \pm \text { SD (range) }\end{array}$ & $\mathbf{N}$ & $\begin{array}{c}2007-2016 \\
\text { mean } \pm \text { SD (range) }\end{array}$ & $\mathbf{N}$ & $\begin{array}{c}1991-2006(4) \\
\text { mean } \pm \text { SD (range) }\end{array}$ \\
\hline lamotrigine & 52 & $250 \pm 108(100 ; 500)$ & 45 & $301 \pm 134^{+}(25 ; 600)$ & 97 & $274 \pm 123(25 ; 600)$ & 27 & $208 \pm 121^{*}(25 ; 500)$ \\
\hline valproic acid & 34 & $746 \pm 369(150 ; 1500)$ & 12 & $854 \pm 464(250 ; 2000)$ & 46 & $774 \pm 393(150 ; 2000)$ & 33 & $767 \pm 337(225 ; 1500)$ \\
\hline carbamazepine & 21 & $564 \pm 203(150 ; 900)$ & 14 & $654 \pm 147(450 ; 900)$ & 35 & $600 \pm 186(150 ; 900)$ & 94 & $513 \pm 223^{* *}(150 ; 1000)$ \\
\hline levetiracetam & 4 & $1313 \pm 851(250 ; 2000)$ & 28 & $1545 \pm 900(500 ; 3500)$ & 32 & $1516 \pm 884(250 ; 3500)$ & - & - \\
\hline topiramate & 6 & $171 \pm 95(25 ; 300)$ & 7 & $214 \pm 48(150 ; 300)$ & 13 & $194 \pm 74(25 ; 300)$ & 3 & $233 \pm 153(100 ; 400)$ \\
\hline clonazepam & 8 & $1.5 \pm 1.3(0.3 ; 4.0)$ & 4 & $0.9 \pm 0.8(0.2 ; 2.0)$ & 12 & $1.3 \pm 1.2(0.2 ; 4.0)$ & 8 & $1.2 \pm 0.5(0.5 ; 2.0)$ \\
\hline phenytoin & 2 & $100 \pm 0(100 ; 100)$ & - & - & 2 & $100 \pm 0(100 ; 100)$ & 53 & $286 \pm 135(40 ; 1000)$ \\
\hline zonisamide & - & - & 2 & $525 \pm 35(500 ; 550)$ & 2 & $525 \pm 35(500 ; 550)$ & - & - \\
\hline primidone & 1 & 500 & - & - & 1 & 500 & 18 & $444 \pm 220(125 ; 750)$ \\
\hline phenobarbital & - & - & - & - & - & - & 8 & $123 \pm 144(9.25 ; 400)$ \\
\hline ethosuximide & - & - & - & - & - & - & 2 & $750 \pm 354(500 ; 1000)$ \\
\hline diazepam & - & - & - & - & - & - & 3 & $8.3 \pm 2.9(5.0 ; 10.0)$ \\
\hline
\end{tabular}

Tab. 3. Daily dose of antiepileptic drugs related to the body weight ( $\mathrm{mg} / \mathrm{kg}$ ) and comparison with our previous study (4); values has not been recorded in all cases

\begin{tabular}{|c|c|c|c|c|c|c|c|c|}
\hline AED & $\mathrm{N}$ & $\begin{array}{c}\text { 2007-2011 } \\
\text { mean } \pm \text { SD (range) }\end{array}$ & $\mathbf{N}$ & $\begin{array}{c}\text { 2012-2016 } \\
\text { mean } \pm \text { SD (range) }\end{array}$ & $\mathbf{N}$ & $\begin{array}{c}2007-2016 \\
\text { mean } \pm \text { SD (range) }\end{array}$ & $\mathbf{N}$ & $\begin{array}{c}1991-2006 \text { (4) } \\
\text { mean } \pm S D \text { (range) }\end{array}$ \\
\hline lamotrigine & 51 & $3.3 \pm 1.4(1.1 ; 6.8)$ & 43 & $3.7 \pm 1.5(0.4 ; 7.1)$ & 94 & $3.5 \pm 1.5(0.4 ; 7.1)$ & 27 & $2.7 \pm 1.5^{*}(0.4 ; 6.2)$ \\
\hline valproic acid & 34 & $10.3 \pm 5.4(1.7 ; 23.1)$ & 10 & $12.4 \pm 6.5(3.0 ; 25.6)$ & 44 & $10.8 \pm 5.7(1.7 ; 25.6)$ & 31 & $10.3 \pm 4.7(2.5 ; 21.3)$ \\
\hline carbamazepine & 21 & $7.5 \pm 2.4(2.2 ; 11.3)$ & 14 & $8.8 \pm 2.5(5.7 ; 14.0)$ & 35 & $8.0 \pm 2.5(2.2 ; 14.0)$ & 90 & $7.0 \pm 3.3^{* * *}(1.6 ; 15.1)$ \\
\hline levetiracetam & 3 & $17.8 \pm 12.4(3.7 ; 26.7)$ & 26 & $19.6 \pm 12.2(6.0 ; 46.2)$ & 29 & $19.4 \pm 12.0(3.7 ; 46.2)$ & - & - \\
\hline topiramate & 6 & $2.6 \pm 1.4(0.4 ; 4.2)$ & 7 & $2.7 \pm 0.7(1.6 ; 3.9)$ & 13 & $2.6 \pm 1.0(0.4 ; 4.2)$ & 2 & $2.8 \pm 2.4(1.1 ; 4.4)$ \\
\hline clonazepam & 7 & $0.023 \pm 0.024(0.004 ; 0.070)$ & 3 & $\begin{array}{l}0.009 \pm 0.010 \\
(0.002 ; 0.020)\end{array}$ & 10 & $0.019 \pm 0.021(0.002 ; 0.070)$ & 5 & $\begin{array}{l}0.012 \pm 0.005 \\
(0.006 ; 0.017)\end{array}$ \\
\hline phenytoin & 2 & $1.5 \pm 0.2(1.3 ; 1.6)$ & - & - & 2 & $1.5 \pm 0.2(1.3 ; 1.6)$ & 48 & $4.0 \pm 1.8(0.5 ; 11.8)$ \\
\hline zonisamide & - & - & 2 & $7.0 \pm 0.4(6.7 ; 7.2)$ & 2 & $7.0 \pm 0.4(6.7 ; 7.2)$ & - & - \\
\hline primidone & 1 & 6.3 & - & - & 1 & 6.3 & 18 & $6.2 \pm 3.1(1.5 ; 12.3)$ \\
\hline phenobarbital & - & - & - & - & - & - & 8 & $1.6 \pm 1.9(0.1 ; 5.3)$ \\
\hline ethosuximide & - & - & - & - & - & - & 2 & $8.0 \pm 2.9(6.0 ; 10.1)$ \\
\hline diazepam & - & - & - & - & - & - & 3 & $0.11 \pm 0.02(0.08 ; 0.13)$ \\
\hline
\end{tabular}

\section{Results}

Monotherapy was used during the first period (2007-2011) in $83 \%$ of women and during the second period (2012-2016) in $68 \%$ of women, which was significantly lower $(p<$ 0.02) (Fig. 1). The most frequently prescribed AEDs independently of mono- and polytherapy were LTG (40.4\%), VPA (26.2 \%) and CBZ (16.3\%) during the first period, and LTG (39.2 \%), LEV (25.6\%) and CBZ (13.6\%) during the second period. CBZ+VPA (25\%) was found as the most widely administered combination of AEDs in the first period and LTG+LEV (37 \%) in the second period (Table 4). Significantly higher total daily doses of LTG were used during the second period in comparison with the first period ( $p<0.04)$ as well as in the sum of both periods ( $p<0.02$ ) compared to our previous study in 1991-2006 (4). Likewise, significantly higher total daily doses of CBZ $(p<0.04)$ were prescribed in the present study (table 2). Daily dose related to the body weight $(\mathrm{mg} / \mathrm{kg}$ ) was seen significantly higher in the sum of both periods ( $p<0.02$ ) compared to the previous study in LTG and higher (but not significantly; $p=0.0563$ ) in CBZ (table 3). Any differences was not found in the dosage of VPA. The patiens were at average older of about two years in the present study $(p<0.0001)$ and have had higher body weight $(p<0.03)$ in the second period compared to the first period (table 1). Trends in the utilization of AEDs during the whole 25-years period (1991-2016) are shown in fig. 2.

\section{Discussion}

Management of AEDS therapy during pregnancy continues to be challenging and conclusions from recent studies are known (1). The major result is that overall the increase in the risk with the frequently used antiepileptic drugs CBZ and LTG in monotherapy is not as great as previously thought but is dependent on the doses. On the other hand, VPA is associated with the highest rates of fetal major congenital malformations than other AEDs in monotherapy as well as in part of polytherapy, followed by phenobarbital (PB) and TPM $(5,6)$. However, the prevalence of AEDs prescribing before, during and after pregnancy varies between different regions of Europe and also in the world. Databases in Denmark, Norway, the Netherlands, Italy (Emilia Romagna/Tuscany), Wales and the Clinical Practice Research Datalink, representing the rest of the United Kingdom (UK), were analysed between 2004 and 2010. In Denmark, Norway and the two UK databases LTG was the most commonly prescribed AED; whereas in the Netherlands and Italian regions, CBZ, VPA and surprisingly PB were most frequently used (7). 2,099 pregnant women were enrolled in FloridaMedicaid from 1999 to 2009 and exposed to AEDs during preg- 


\section{ILAVNÍ TÉMA}

TREND ANALYSIS OF THE UTILIZATION OF ANTIEPILEPTIC DRUGS In PREGNANT WOMEN WITH EPILEPSY IN MORAVIAN-SILESIAN REGION OF THE CZECH REPUBLIC

Tab. 4. A: utilization of individual antiepileptic drugs during two study periods and comparison with first 5 years of our previous study (4), B: utilization of combinations of antiepileptic drugs during two study periods and comparison with first 5 years of our previous study (4)

\begin{tabular}{|c|c|c|c|c|c|}
\hline A: & $2007-2011$ & & 2012-2016 & & 1991-1995 (4) \\
\hline AED & $\mathrm{N}(\%)$ & AED & N (\%) & AED & N (\%) \\
\hline LTG & 57 (40.4\%) & LTG & $49(39.2 \%)$ & PHT & $34(45.3 \%)$ \\
\hline VPA & 37 (26.2 \%) & LEV & $32(25.6 \%)$ & $\mathrm{CBZ}$ & $18(24.0 \%)$ \\
\hline CBZ & $23(16.3 \%)$ & CBZ & $17(13.6 \%)$ & PRM & 7 (9.3\%) \\
\hline$C L Z$ & $10(7.1 \%)$ & VPA & $13(10.4 \%)$ & PB & $6(8.0 \%)$ \\
\hline TPM & $6(4.3 \%)$ & TPM & $7(5.6 \%)$ & $C L Z$ & $4(5.3 \%)$ \\
\hline LEV & $5(3.5 \%)$ & $\mathrm{CLZ}$ & $4(3.2 \%)$ & DIA & $3(4.0 \%)$ \\
\hline PHT & $2(1.4 \%)$ & ZNS & $2(1.6 \%)$ & ETS & $2(2.7 \%)$ \\
\hline PRM & $1(0.7 \%)$ & DIA & $1(0.8 \%)$ & VPA & $1(1.3 \%)$ \\
\hline \multicolumn{6}{|l|}{ B: } \\
\hline $\mathrm{CBZ}+\mathrm{VPA}$ & $5(25 \%)$ & LTG + LEV & $11(37 \%)$ & $\mathrm{CBZ}+\mathrm{PHT}$ & $7(35 \%)$ \\
\hline $\mathrm{CBZ}+\mathrm{CLZ}$ & $2(10 \%)$ & CBZ + LEV & $4(13 \%)$ & $\mathrm{PHT}+\mathrm{PB}$ & $3(15 \%)$ \\
\hline VPA+LTG & $2(10 \%)$ & CBZ + LTG & $3(10 \%)$ & $\mathrm{PHT}+\mathrm{CLZ}$ & $2(10 \%)$ \\
\hline LTG+LEV & $2(10 \%)$ & $V P A+L T G$ & $2(7 \%)$ & PRM + ETS & $1(5 \%)$ \\
\hline CBZ+LTG & $1(5 \%)$ & $\mathrm{LEV}+\mathrm{CLZ}$ & $2(7 \%)$ & $C B Z+D I A$ & $1(5 \%)$ \\
\hline CBZ+TPM & $1(5 \%)$ & LEV + ZNS & $2(7 \%)$ & $\mathrm{PHT}+\mathrm{ETS}$ & $1(5 \%)$ \\
\hline $\mathrm{LTG}+\mathrm{CLZ}$ & $1(5 \%)$ & $C B Z+T P M$ & $1(3 \%)$ & $\mathrm{PHT}+\mathrm{PRM}$ & $1(5 \%)$ \\
\hline $\mathrm{VPA}+\mathrm{PHT}$ & $1(5 \%)$ & $C B Z+V P A$ & $1(3 \%)$ & $\mathrm{CBZ}+\mathrm{PHT}+\mathrm{PRM}$ & $1(5 \%)$ \\
\hline VPA+TPM & $1(5 \%)$ & $V P A+L E V$ & $1(3 \%)$ & $C B Z+P R M+D I A$ & $1(5 \%)$ \\
\hline VPA+LTG+LEV & $1(5 \%)$ & $V P A+D I A$ & $1(3 \%)$ & $\mathrm{PHT}+\mathrm{CLZ}+\mathrm{DIA}$ & $1(5 \%)$ \\
\hline VPA+LTG+TPM & $1(5 \%)$ & LEV + TPM & $1(3 \%)$ & $\mathrm{CBZ}+\mathrm{PHT}+\mathrm{VPA}+\mathrm{PB}$ & $1(5 \%)$ \\
\hline $\mathrm{CBZ}+\mathrm{PRM}+\mathrm{LTG}$ & $1(5 \%)$ & $V P A+L T G+L E V$ & $1(3 \%)$ & & \\
\hline$C B Z+V P A+C L Z$ & $1(5 \%)$ & & & & \\
\hline
\end{tabular}

nancy. The secular trends for AEDs use in poly- or monotherapy did not significantly vary over time (polytherapy was 62\% in 2000 and 63\% in 2009). The use of first-generation AEDs decreased, whereas the use of second-generation AEDs increased. CBZ, PHT and VPA were the three most frequently used AEDs in pregnant women from 2002 to 2004. In 2005, LTG replaced CBZ as the most frequently used AED. In 2007, LEV surpassed VPA and became the most frequently used AED next to LTG (8). The North American Antiepileptic Drug Pregnancy Registry enrolled between February 1997 and April 2014 a total of 8,826 pregnant women who were taking AEDs. Of these participants, 5,637 (64\%) were taking an AED as monotherapy in the first trimester of pregnancy. LEV, LTG, TPM and CBZ were the most frequently used AEDs (9). A Central Registry of Antiepileptic Drugs and Pregnancy (EURAP) accumulate data since 1999 and the present report is based on data available by May 20th, 2016. A total 12,256 prospective pregnancies are included in this report. Of the pregnancies, 9,828 (80.2\%) involved women on a single AED, 1,948 (15.9\%) were on two AEDs whereas 341 (2.8\%) took three AEDs or more. The most frequently prescribed AEDs were LTG, CBZ, VPA and LEV and the combinations LTG+VPA, LTG+LEV and CBZ+LEV (10). Pregnant women with epilepsy ( $N=855$ ) enrolled in the Australian Register of Antiepileptic Drugs in Pregnancy during 1999-2005 were compared with the corresponding data for the 801 women enrolled from 2006-2012. AED were used in monotherapy more often in the 2006-2012 cohort, and there were statistically significant reductions in the rates at which „older" AEDs (CBZ, VPA, PHT and gabapentin) were prescribed for the pregnant women, though rates of prescribing LTG and clonazepam (CLZ) remained relatively unaltered. Compensating for the falling prescribing rates for many of the "older" AEDs, there were statistically significant increases in prescribing rates for LEV and TPM. There were no statistically signifiant alterations in mean doses of any of the drugs used, except for VPA, for which the mean daily dose fell from $1061 \pm 702 \mathrm{mg} /$ day to $748 \pm 399 \mathrm{mg} /$ day (11). The country's differences in prescribing patterns may suggest different use, knowledge or interpretation of the scientific evidence base (7). In our present study the most frequently prescribed AEDs were LTG, VPA and CBZ between 2007-2011, and LTG, LEV and CBZ during 2012-2016, whereas

Figure 1. Mono-versus polytherapy of AEDs; comparison with our previous study (4)

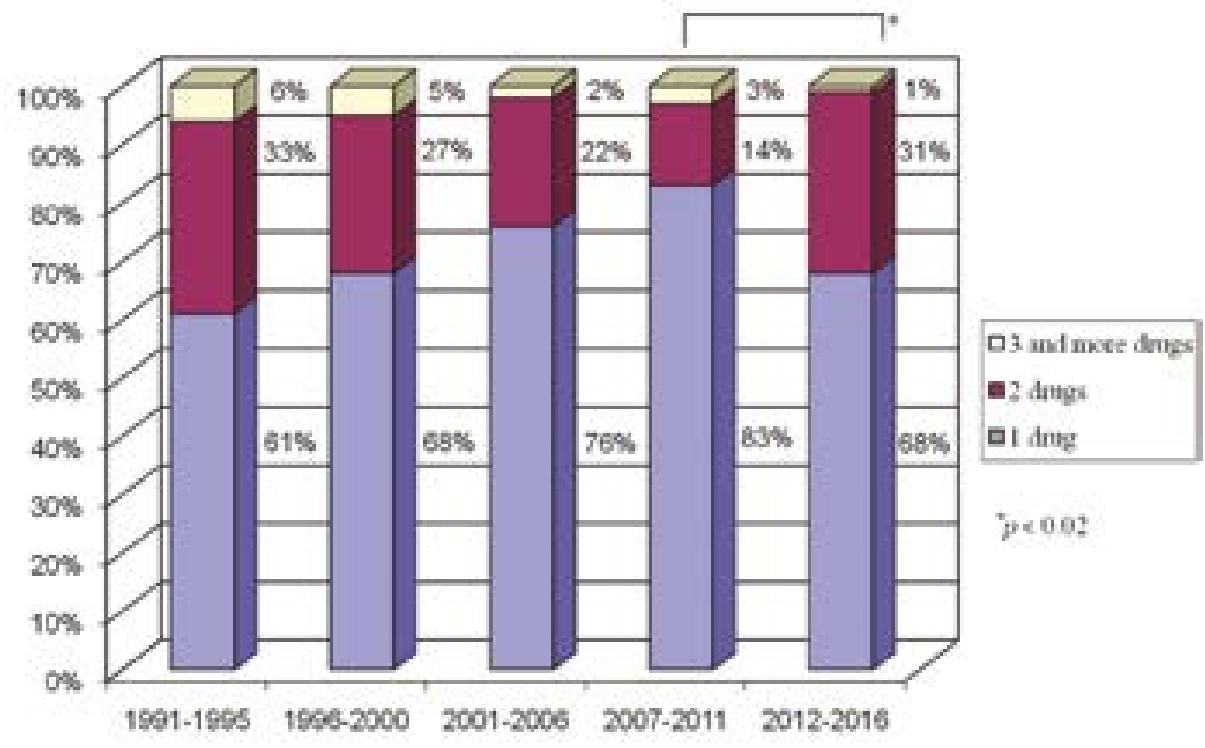


Figure 2. Trends in the use of antiepileptic drugs between January 1991 and May 2016 (with exception of diazepam, ethosuximide and zonisamide, which utilization was under $5 \%$ )

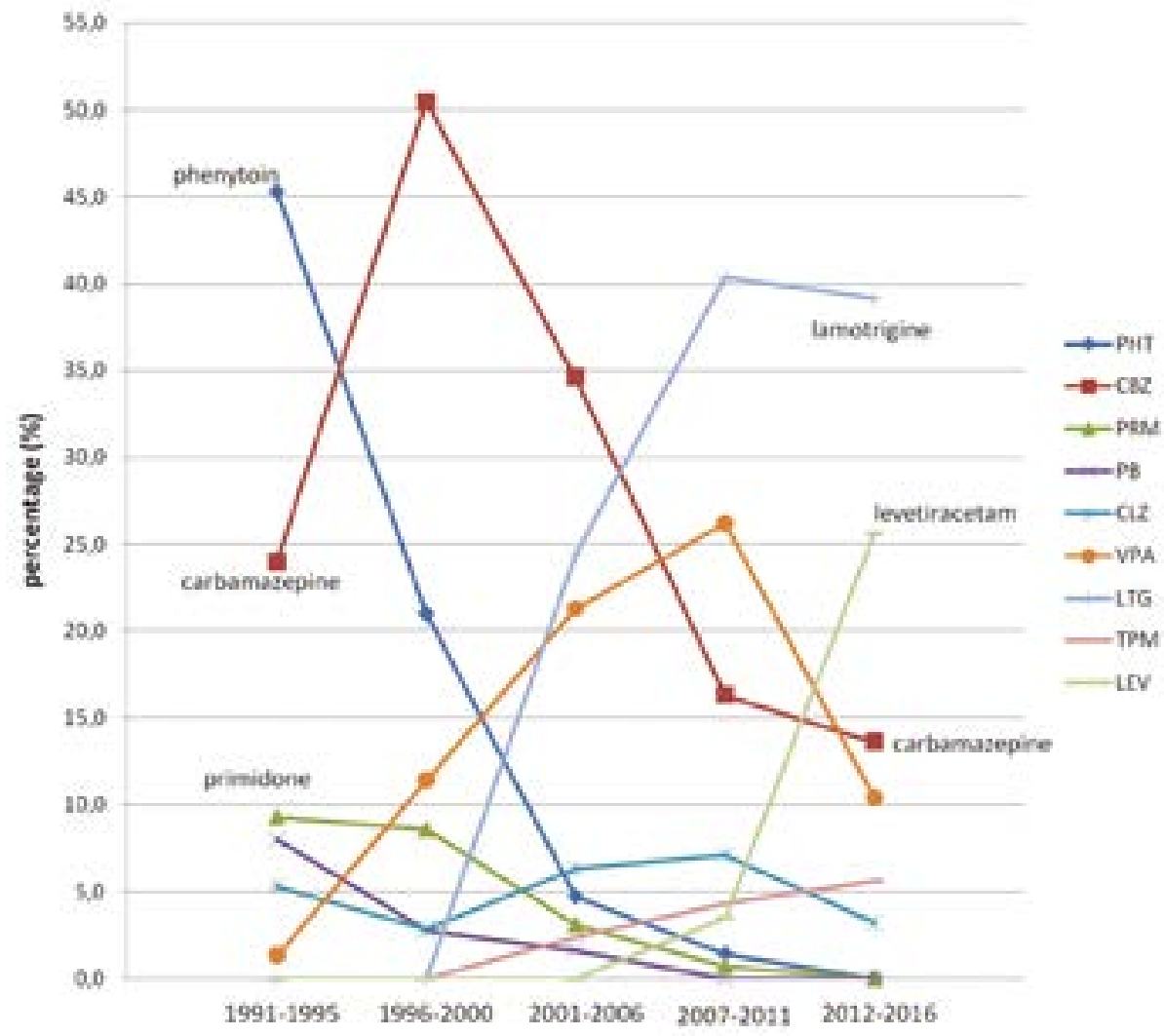

PHT, CBZ and PRM were the mose frequently used AEDs (4) in the beginning of the whole 25-years study period (table 4, figure 2). The result is in good agreement with international recommendations (1). On the other hand, monotherapy was used during the second study period (2012-2016) only in $68 \%$ of women, which was significantly lower in comparison with the first study period (2007-2011). Nevertheless, $90 \%$ of all combinations prescribed during the second period contained LEV, LTG or both. Significantly higher doses of LTG and CBZ were used during the present study (2007-2016) in comparison with the previous study (1991-2006) (4). Any differences was not found in the dosage of VPA, the mean daily dose was $774 \pm 393 \mathrm{mg} /$ day during 2007-2016 versus $767 \pm 337 \mathrm{mg} /$ day during 1991-2006 (4), which is in agreement with the Australian Register (11) and slightly higher compared to international recommendations (1). Physiological changes during pregnancy al-

\section{REFERENCES}

1. Patel SI, Pennell PB. Management of epilepsy during pregnancy: an update. Ther Adv Neurol Disord 2016; 9(2): 118-129.

2. Tomson T, Xue H, Battino D. Major congenital malformations in children of women with epilepsy. Seizure 2015; 28: 46-50. 3. Kacirova I, Grundmann M, Brozmanova H. Serum levels of valproic acid during delivery in mothers and in umbili- ter the pharmacokinetics of AEDs, which may result in lower levels and seizure deterioration (1). Pregnancy can affect the pharmacokinetics of AEDs at any level from absorption, distribution, metabolism, to elimination. The effects of pregnancy on serum concentrations vary depending on the type of AED and differ also individually and are thus difficult to predict. The most pronounced decline in serum concentrations is seen for AEDs that are eliminated by glucuronidation, in particular LTG where the effect may be profound. Serum concentrations of AEDs that are cleared mainly through the kidneys, for example, levetiracetam LEV, can also decline significantly (12-14). Polytherapy makes it even more difficult to predict the course of AED concentrations during pregnancy. Therapeutic monitoring of AEDs is effective in preventing seizure deterioration for women with epilepsy during pregnancy. In addition, monitoring of AEDs levels in the mother and the neonate at cal cord - correlation with birth length and weight. Biomed Pap Med Fac Univ Palacky Olomouc Czech Repub 2015;

4. Kacirova I, Grundmann M, Koristkova B, Brozmanova H. Development of a treatment of pregnant women suffering from epilepsy in the region of Ostrava between the years 1991 and 1996. Ces slov Farm 2010; 59(4): 172-178. 159(4): 569-575 birth (the umbilical cord) serves as a closer surrogate marker for fetal exposure $(3,15-17)$.

\section{Conclusion}

Our study demonstrates long-term trends in the utilization of AEDs in pregnant women with epilepsy. A significant shift from PHT, CBZ and PRM to CBZ, LTG and VPA was found between 1991-2006, and from LTG, VPA and CBZ to LTG, LEV and CBZ between 2007-2016. Prescription of the AED with the highest teratogenic risk (VPA) has declined during 2007-2016 with an increase in the use of "newer" AEDs (most notably LTG and LEV), which is concordant with current recommendations. On the other hand, monotherapy has decreased with an increase in the use of LEV. Therapeutic drug monitoring of AEDs during pregnancy and after delivery can be helpful to optimize the treatment in women suffering from epilepsy in this period of unstable kinetics. Especially, the top two most frequently used antiepileptic drugs LTG and LEV, which have increased clearance with changes in plasma levels during pregnancy, require close monitoring.

\section{Abreviations}

AEDs - antiepileptic drugs

CBZ - carbamazepine

CLZ - clonazepam

DIA - diazepam

ETS - ethosuximide

EURAP - International Antiepileptic Drugs and

Pregnancy Registry

LEV - levetiracetam

LTG - lamotrigine

MCM - major congenital malformations

$\mathrm{N}$ - number

PB - phenobarbital

PHT - phenytoin

PRM - primidone

TDM - therapeutic drug monitoring

TPM - topiramate

UK - United Kingdom

VPA - valproic acid

ZNS - zonisamide
5. Tomson T, Bonizzoni E, Craig J, et al. Dose-dependent risk of malformations with antiepilepticdrugs: an analysis of data from the EURAP epilepsy and pregnancy registry. Lancet Neurol 2011; 10: 609-616.

6. Hernandez-Diaz S, Smith C, Shen A, et al. Comparative safety of antiepileptic drugs during pregnancy. Neurology 2012; 78: 1692-1699. 


\section{| HLAVNÍ TÉMA}

TREND ANALYSIS OF THE UTILIZATION OF ANTIEPILEPTIC DRUGS IN PREGNANT WOMEN WITH EPILEPSY IN MORAVIAN-SILESIAN REGION OF THE CZECH REPUBLIC

7. Charlton R, Garne E, Wang H, et al. Antiepileptic drug prescribing before, during and after pregnancy: a study in seven European regions. Pharmacoepidemiol Drug Saf 2015; 24(11): 1144-1154.

8. Wen X, Meador KJ, Hartzema A. Antiepileptic drug use by pregnant women enrolled in Florida Medicaid. Neurology 2015; 84(9): 944-950.

9. http://www.aedpregnancyregistry.org/

10. http://www.eurapinternational.org/pdf/private/reports/ Rep_May_2016.pdf.

11. Vajda FJ, O’Brien TJ, Graham J, Lander CM, Eadie MJ. The
Australian Register of antiepileptic drugs in pregnancy: changes over time in the epileptic population. J Clin Neurosci 2014 21(9): 1478-1482.

12. Leppik IE, Rask CA. Pharmacokinetics of antiepileptic drugs during pregnancy. Semin Neurol 1988; 8(3): 240-246. 13. Battino D, Tomson T, Bonizzoni E, et al. Seizure control and treatment changes in pregnancy: observations from the EURAP epilepsy pregnancy registry. Epilepsia 2013; 54(9): 1621-1627. 14. Tomson T, Landmark CJ, Battino D. Antiepileptic drug treatment in pregnancy: changes in drug disposition and their clinical implications. Epilepsia 2013; 54(3): 405-414.
15. Pennell PB, Hovinga CA. Antiepileptic drug therapy in pregnancy I: gestation-induced effects on AED pharmacokinetics. Int Rev Neurobiol 2008; 83: 227-240.

16. Kacirova I, Grundmann M, Brozmanova H. Serum levels of lamotrigine during delivery in mothers and their infants. Epilepsy Res 2010; 91: 161-165.

17. Kacirova I, Grundmann M, Brozmanova H. Concentrations of carbamazepine and carbamazepine-10,11-epoxide in maternal and umbilical cord blood at birth: Influence of co-administration of valproic acid or enzyme-inducing antiepileptic drugs. Epilepsy Res 2016; 122: 84-90. 